\title{
Kadar Interferon Gamma Kultur Sel Limfosit pada Anak yang Mendapat Vaksinasi BCG
}

\author{
Liza Fitria,* Andani Eka Putra,** Finny Fitry Yani,* Darfioes Basir* \\ *Bagian Ilmu Kesehatan Anak, **Bagian Mikrobiologi Fakultas Kedokteran Universitas Andalas/RSUP DR.M.Djamil, Padang
}

\begin{abstract}
Latar belakang. Vaksinasi BCG mempunyai efek proteksi yang bervariasi, menurun dengan bertambahnya umur anak. Perkembangan pengetahuan di bidang biologi molekuler telah mengembangkan pemeriksaan IFN- $\gamma$ untuk mendeteksi respon vaksinasi.

Tujuan. Mengetahui lamanya efek proteksi BCG dan hubungan kadar IFN- $\gamma$ dengan umur, status gizi, umur mendapatkan vaksinasi BCG dan sarana kesehatan tempat vaksinasi.

Metode. Suatu studi cross sectional, stratified random sampling, pada anak yang telah mendapat vaksinasi BCG. Kadar IFN- $\gamma$ diukur dari sel limfosit yang telah dikultur. Analisis statistik menggunakan uji Anova dan Independent sample t tes.

Hasil. Kadar IFN- $\gamma$ tertinggi pada kelompok umur 4-11 bulan. Terdapat perbedaan bermakna kadar IFN- $\gamma$ antara kelompok umur 4-11 bulan dengan 1-4 tahun dan 1-4 tahun dengan 5-9 tahun. Tidak terdapat perbedaan bermakna antara status gizi, umur mendapatkan vaksinasi BCG, sarana kesehatan tempat vaksinasi BCG dengan kadar IFN- $\gamma$.

Kesimpulan. Kadar IFN- $\gamma$ yang tinggi menunjukkan vaksinasi BCG efektif pada anak, tetapi efektifitasnya menurun seiring dengan pertambahan umur. Sari Pediatri 2016;18(1):21-6
\end{abstract}

Kata kunci: vaksinasi BCG pada anak, umur, IFN- $\gamma$

\section{Interferon-Gamma Levels in Lymphocyte Cell Cultures from BCG Vaccinated Children}

Liza Fitria, Finny Fitry Yani, Andani Eka Putra, Darfioes Basir

Background. Level of protection from BCG vaccination against pulmonary tuberculosis varies widely in different populations. Many studies reveal that efficacy of the vaccine wanes with age. The molecular biology science has further developed with ability to measure Interferon-gamma (IFN- $\gamma$ ) level as a measurement to detect the effect of this vaccination.

Objective. To determine the duration of BCG vaccine protection effect and the relationship between IFN- $\gamma$ levels with age, nutritional status, age range for BCG vaccination and health center's facilities for BCG vaccination.

Methods. A cross sectional, stratified random sampling, BCG vaccinated children. IFN- $\gamma$ was measured from induced in lymphocyte cultures. Statistical analysis was performed using Anova and independent sample t tes.

Results. The highest IFN- $\gamma$ levels were among 4-11 month age group. Statistically, there was a significant correlation of IFN- $\gamma$ levels between the 4-11 month and 1-4 year age groups as well as between the 1-4 year and 5-9 year age groups. There was no significant correlation between IFN- $\gamma$ levels with nutritional status, age range for vaccination and health center's facilities for vaccination.

Conclusion. High levels of IFN- $\gamma$ showed that BCG vaccination is an effective vaccination for children; however its effectiveness decreases with age. Sari Pediatri 2016;18(1):21-6

Keywords: BCG vaccination, age, IFN- $\gamma$

Alamat korespondensi: Dr.Finny Fitry Yani, SpA(K), Dr. Liza Fitria. Departemen Ilmu Kesehatan Anak FK-UNAND/RSUP Dr. M. Djamil Jl. Perintis Kemerdekaan. Padang, Sumatera Barat. Telp+62-751-811179. Fax.+62-751-811179. Email: Finny_fy@yahoo.com, lizafitria81@yahoo.com 
$\mathrm{V}$ aksin Bacille Calmette-Guerin (BCG) mulai dikembangkan tahun 1906 oleh Albert Calmette dan Camilla Guerin yang mengandung Mycobacterium bovis yang dilemahkan. Vaksin ini sudah digunakan sejak tahun 1921 berkaitan dengan program pencegahan terhadap tuberkulosis (TB) yang disebabkan Mycobacterium tuberculosis (M.tb). ${ }^{1}$ Efek proteksi BCG sangat bervariasi, 0\%-80\% sehingga TB masih merupakan masalah kesehatan masyarakat yang utama di seluruh dunia. ${ }^{1-3}$ Indonesia berkontribusi lebih dari 50\% kasus TB. Tuberkulosis anak merupakan faktor penting di negara berkembang karena jumlah anak berusia $<15$ tahun adalah $40 \%-50 \%$ jumlah seluruh populasi. ${ }^{4}$

Beberapa penelitian menunjukkan bahwa BCG hanya mampu mencegah sakit berat, seperti kasus TB milier atau meningitis TB, tetapi tidak dapat mencegah perkembangan fase laten atau reaktivasi. Efek proteksi terhadap tuberkulosis berat ini diduga lebih banyak berkaitan dengan efek imunomodulator vaksin ini dibanding efek proteksi spesifik terhadap tuberkulosis..$^{5-7}$ Pengaruh BCG yang berkurang juga dilaporkan oleh peneliti lain, tetapi hasilnya sebagian besar didasarkan pada uji tuberkulin. ${ }^{8}$ Meskipun uji tuberkulin telah terbukti berguna dalam praktek klinis, tetap memiliki beberapa keterbatasan utama. Uji tuberkulin bukan indikator ideal status vaksinasi BCG. Tes baru seperti uji IFN- $\gamma$ in vitro dan identifikasi protein mikobakteri imunogenik yang kuat, perlu untuk menguatkan pengamatan sebelumnya. ${ }^{9}$ Peningkatan IFN- $\gamma$ sebagai respon terhadap BCG berkorelasi baik dengan tingkat perlindungan oleh vaksinasi $\mathrm{BCG} .{ }^{10}$ Berdasarkan hal tersebut, ingin diketahui sejauh mana kadar IFN- $\gamma$ bertahan pada anak yang mendapat vaksinasi BCG.

\section{Metode}

Penelitian cross sectional dilakukan di poliklinik dan bangsal anak RS Dr. M. Djamil Padang bulan Februari 2012 - April 2013. Kultur sel limfosit dan pemeriksaan IFN- $\gamma$ dilakukan di laboratorium biomedik fakultas kedokteran Universitas Andalas. Populasi penelitian adalah anak yang mendapat vaksinasi BCG. Sampel didapatkan dengan cara stratified random sampling. Kriteria inklusi adalah anak berumur 4 bulan -14 tahun, mempunyai scar BCG dan mendapat persetujuan orang tua. Pasien yang pernah menderita
TB atau mendapat OAT, pernah tuberculin skin test (TST) dalam waktu kurang 2 minggu. sedang mendapat terapi kortikosteroid lebih 2 minggu, pasien dengan imunocompromaise, menderita keganasan, dan peningkatan kadar IFN- $\gamma>100 \mathrm{pg} / \mathrm{mL}$ setelah induksi dengan antigen TB (ESAT-6), dikeluarkan dari penelitian.

Subjek penelitian adalah 40 anak tiap kelompok umur yang memenuhi kriteria inklusi, dibagi atas kelompok umur 4-11 bulan, 1-4 tahun, 5-9 tahun, 10-14 tahun. Pengambilan darah vena perifer sebanyak $\pm 2,5 \mathrm{~mL}$ dan segera diperiksa dalam 1x24 jam. Langkah pertama setelah pengambilan darah adalah isolasi dan kultur limfosit. Setelah 7 hari, supernatan diambil dan diukur kadar IFN- $\gamma$ menggunakan Elisa Reader. Konsentrasi IFN- $\gamma$ dihitung berdasarkan kurva standar yang dibuat dari IFN- $\gamma$ standar.

Dilakukan analisis hubungan antara variabel umur, status gizi, sarana kesehatan tempat mendapatkan vaksin, masing-masing dengan hasil pemeriksaan IFN- $\gamma$ dengan uji statistik Anova dan waktu pemberian vaksinasi dengan uji independent sample t test.

\section{Hasil}

Didapatkan 160 subjek penelitian sesuai dengan kriteria inklusi. Enambelas subjek dieksklusi karena peningkatan kadar IFN- $\gamma$ yang diinduksi ESAT-6. Tabel 1 menunjukkan karakteristik subjek penelitian. Kadar IFN- $\gamma$ tertinggi pada kelompok umur 4-11 bulan $(461,9$ (SD 169,3) pg/mL), secara stastistik terdapat perbedaan bermakna antara kadar IFN- $\gamma$ dengan kelompok umur $(\mathrm{p}=0,000)$ (Tabel 2). Konsentrasi IFN- $\gamma$ tampak semakin berkurang dengan bertambahnya umur, seperti tertera pada Gambar 1.

Uji statistik Anova pada keempat kelompok umur menunjukkan terdapat perbedaan yang bermakna antara kadar IFN- $\gamma$ dengan kelompok umur $(\mathrm{p}=0,000)$. Analisis post hoc dengan least significant difference (LSD) memperlihatkan perbedaan bermakna kadar IFN- $\gamma$ antara kelompok umur 4-11 bulan dengan 1-4 tahun $(\mathrm{p}=0,028)$ dan antara 1-4 tahun dengan 5-9 tahun $(\mathrm{p}=0,000)$.

Perbedaan bermakna kadar IFN- $\gamma$ tidak ditemukan antara periode 5-9 tahun dengan 10-14 tahun ( $\mathrm{p}=0,344)$. Hasil uji korelasi antara kadar IFN $-\gamma$ yang diinduksi BCG dengan umur memperlihatkan nilai $\mathrm{r}=-0,590$ dan $\mathrm{p}=0,000$. 
Tabel 1. Karakteristik subjek penelitian

\begin{tabular}{lcc}
\hline Karakteristik & F & $\%$ \\
\hline Umur & & \\
$4-11$ bulan & 35 & 24,3 \\
$1-4$ tahun & 35 & 24,3 \\
$5-9$ tahun & 39 & 27,1 \\
10-14 tahun & 35 & 24,3 \\
Jenis kelamin & & \\
Laki-laki & 68 & 47,2 \\
Perempuan & 76 & 52,8 \\
Status gizi & & 4,9 \\
Lebih & 7 & 41,0 \\
Baik & 59 & 54,1 \\
Kurang & 78 & 86,8 \\
Umur mendapatkan vaksinasi BCG (bulan) & & 13,2 \\
$\quad 1$ & 125 & \\
$>1-2$ & 19 & 38,2 \\
Sarana kesehatan tempat vaksinasi BCG & & 57,6 \\
Posyandu & & 4,2 \\
Puskesmas & 55 & \\
Rumah sakit & 83 & 6 \\
\end{tabular}

Tabel 2. Kadar IFN- $\gamma$ kultur sel limfosit dari subjek penelitian

\begin{tabular}{lccc}
\hline Karakteristik & $\begin{array}{c}\text { Kontrol, Rerata }(\mathrm{SD}) \\
\mathrm{pg} / \mathrm{mL}\end{array}$ & $\begin{array}{c}\text { Protein induksi BCG, rerata } \\
(\mathrm{SD}) \mathrm{pg} / \mathrm{mL}\end{array}$ & Nilai p \\
\hline Umur & $20,9(14,2)$ & $461,9(169,3)$ & 0,000 \\
$\quad$ 4-11 bulan & $16,1(10,7)$ & $391,4(127,0)$ & \\
$1-4$ tahun & $18,3(14,4)$ & $237,8(97)$ & \\
5-9 tahun & $24,2(14,9)$ & $208,5(130,4)$ & \\
$\quad$ 10- 14 tahun & & & 0,149 \\
Status gizi & $9,8(5,7)$ & $285,6(110.3)$ & \\
$\quad$ Lebih & $22,1(15,7)$ & $355,1(177,9)$ & \\
$\quad$ Baik & $19,1(12,4)$ & $301,2(162,1)$ & \\
$\quad$ Kurang & & & \\
Umur mendapatkan vaksinasi & & & \\
BCG (bulan) & $19,9(14,3)$ & $314,5(160,8)$ & \\
$\quad \leq 1$ & $19,2(10,9)$ & $375,4(207,1)$ & \\
$\quad>1-2$ & & & \\
Sarana kesehatan tempat & & & \\
mendapatkan vaksinasi BCG & $17,8(11,6)$ & $348,8(182,4)$ & \\
$\quad$ Posyandu & $21,4(15,1)$ & $306,8(161,5)$ & \\
$\quad$ Puskesmas & $17,9(14,4)$ & $299,1(107,5)$ & \\
$\quad$ Rumah Sakit & &
\end{tabular}




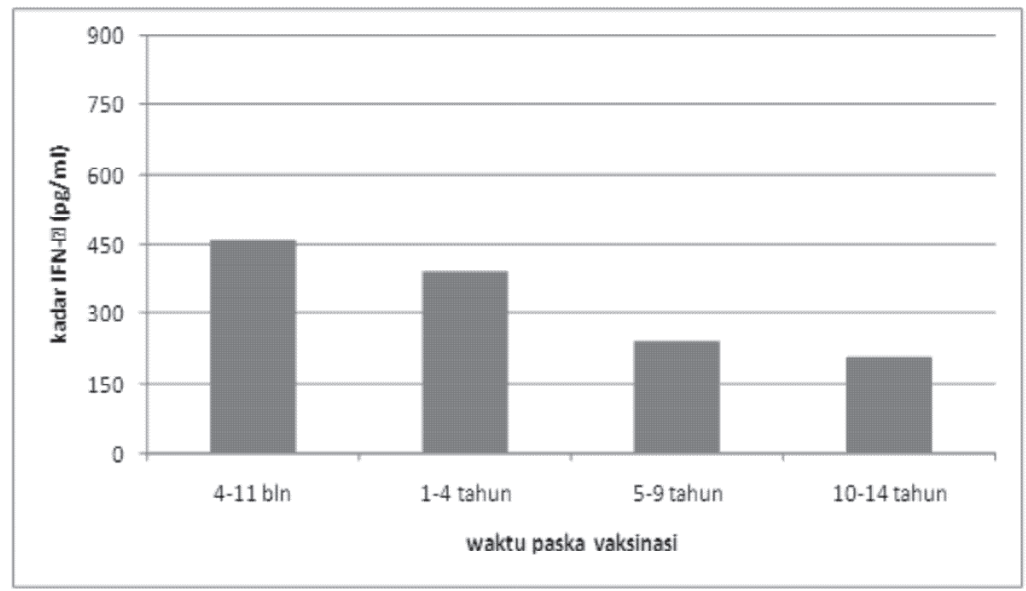

Gambar 1. Perbandingan kadar IFN- $\gamma$ yang diinduksi protein BCG berdasarkan waktu pasca vaksinasi

\section{Pembahasan}

Terdapat peningkatan kadar IFN- $\gamma$ setelah diinduksi ESAT-6 yang merupakan protein spesifik M.tb. Perlu penelusuran lebih lanjut untuk deteksi infeksi M.tb pada sampel penelitian tersebut. Penggunaan ESAT-6 sebagai protein induktor merupakan protein spesifik kuman M.tb, tetapi tidak ditemukan pada vaksin BCG. ${ }^{11} \mathrm{Hal}$ tersebut berkaitan dengan evolusi mikobakteria, lokus RD1 yang memuat gene ESAT-6 telah mengalami delesi pada $\mathrm{M}$. bovis strain BCG. ${ }^{12}$ Fenomena tersebut juga menjelaskan mengapa titer IFN- $\gamma$ pasca induksi ESAT-6 tidak dipengaruhi oleh vaksinasi BCG.

Kadar IFN- $\gamma$ yang diinduksi BCG didapatkan tertinggi pada kelompok umur 4-11 bulan. Hal tersebut menunjukkan penurunan respon sel $\mathrm{T}$ memori yang signifikan setelah anak berumur lebih dari 1 tahun. Uji korelasi menunjukkan nilai signifikan dan korelasi sedang antara kadar IFN- $\gamma$ dengan umur.

Penelitian yang menggunakan uji tuberkulin untuk menilai respon vaksinasi BCG melaporkan bahwa lebih $50 \%$ bayi yang mendapat BCG saat lahir tidak reaktif lagi terhadap uji tuberkulin saat berumur 9-12 bulan dan negatif setelah berumur 5 tahun. ${ }^{13}$ Briassoulis $\mathrm{dkk}^{14}$ menilai efektifitas BCG umur 6, 12, dan 15 tahun melaporkan menurun setelah umur 12 tahun. Penelitian Anuradha dkk ${ }^{15}$ melaporkan bahwa kadar IFN- $\gamma$ pada umur kurang 6, 6-8, dan 9-12 tahun berturut-turut adalah $3316 \pm 718,2880 \pm 733$, dan
$1360 \pm 344 \mathrm{pg} / \mathrm{ml}$. Penurunan respon BCG dengan pertambahan umur dan penurunan bermakna pada umur 9-12 tahun dibuktikan dengan insiden TB yang tinggi di India pada umur 10-14 tahun (15,4$16,9 \%)$. Penelitian Kalpana $\mathrm{dkk}^{16}$ pada anak umur 5-8 tahun mengukur kadar IFN- $\gamma$ yang distimulasi BCG disertai uji tuberkulin melaporkan bahwa kadar IFN- $\gamma$ tinggi pada anak yang telah divaksinasi BCG dengan uji tuberkulin positif. Respon IFN- $\gamma$ yang kurang pada anak dengan vaksinasi BCG dan uji tuberkulin negatif disebabkan karena tidak adanya sel T memori dan mengindikasikan vaksinasi yang sudah tidak efektif. Penelitian Djuardi $\mathrm{dkk}^{17}$ melaporkan kadar IFN- $\gamma$ meningkat hanya sampai umur 2 tahun. Beberapa penelitian telah memperlihatkan bahwa BCG efektif diberikan pada anak, tetapi efektifitasnya menurun dengan bertambahnya umur. Imunitas dapat ditingkatkan dengan memberikan boster vaksin modifikasi dari BCG seperti $\mathrm{r} 32 \mathrm{kDa}(\mathrm{Ag} 85 \mathrm{~A}){ }^{15}$

Indikator $\mathrm{BB} / \mathrm{TB}$ merupakan indikator yang baik untuk menyatakan status gizi. ${ }^{18}$ Kadar IFN- $\gamma$ yang diinduksi BCG tertinggi pada status gizi baik, tetapi tidak didapatkan perbedaan antara kadar IFN- $\gamma$ yang diinduksi BCG dengan status gizi. Hal tersebut disebabkan distribusi subjek yang tidak merata, jumlah subjek terlalu sedikit pada kelompok gizi lebih sehingga rerata kadar IFN- $\gamma$ yang dihasilkan lebih rendah dibandingkan kelompok gizi kurang dan gizi baik. Di samping itu, pada penelitian ini diperiksa kadar IFN- $\gamma$ dari kultur sel limfosit yang diperlakukan pada 
medium dengan nutrisi yang sama. Namun, penelitian Zaldivar $\mathrm{dkk}^{19}$ melaporkan peningkatan respon sitokin proinflamasi pada kelompok gizi lebih berhubungan dengan peningkatan jumlah limfosit.

Seratus duapuluh lima $(86,8 \%)$ subjek mendapat vaksin BCG saat berumur kurang dari satu bulan, sedangkan penelitian Djuardi $\mathrm{dkk}^{17}$ melaporkan vaksinasi BCG paling banyak umur $\leq 1$ bulan $47 \%$ dan $>1$ bulan 53\%. Pemeriksaan kadar IFN- $\gamma$ yang diinduksi BCG lebih tinggi pada vaksinasi yang diberikan umur $>1-2$ bulan dibandingkan dengan vaksinasi yang diberikan pada umur $\leq 1$ bulan. Berdasarkan uji statistik independent sample $t$ test tidak didapatkan perbedaan bermakna antara kadar IFN- $\gamma$ dengan waktu pemberian vaksinasi. Terjadinya antibodi spesifik pada pejamu terhadap vaksin yang diberikan akan memengaruhi keberhasilan vaksinasi. Keberhasilan vaksinasi juga memerlukan maturitas imunologik. Pada neonatus fungsi makrofag masih kurang, terutama fungsi mempresentasikan antigen karena ekspresi MHC masih kurang, selain deformabilitas membran serta respon kemotaktik yang masih kurang. ${ }^{20}$ Pada tahun 2011, Ikatan Dokter Anak Indonesia (IDAI) mulai merekomendasikan pemberian vaksinasi BCG optimal pada umur 2-3 bulan. ${ }^{20}$

Pemeriksaan kadar IFN- $\gamma$ yang diinduksi BCG pada vaksinasi yang dilakukan di Posyandu lebih tinggi, tetapi setelah dilakukan uji statistik tidak didapatkan perbedaan. Distribusi subjek tidak merata. Penyimpanan dan transportasi vaksin harus diperhatikan untuk menjamin potensinya sebelum diberikan kepada anak.

\section{Kesimpulan}

Kadar IFN- $\gamma$ setelah vaksinasi BCG berbanding terbalik dengan umur. Kadar IFN- $\gamma$ menurun setelah anak berumur 1 tahun. Kadar IFN- $\gamma$ menunjukkan vaksinasi BCG yang efektif pada anak, efektifitasnya menurun seiring dengan pertambahan umur.

\section{Daftar pustaka}

1. Barreto ML, Pereira SM, Ferreira A. BCG vaccine: efficacy and indications for vaccination and revaccination. J Pediatr 2006;82:45-54.

2. World Health Organization. Guidance for national tuberculosis programmes on the management of tuberculosis in children. Geneva: WHO; 2006.

3. World Health Organization report. Global tuberculosis control. Geneva: WHO; 2011.

4. Donald PR. Childhood tuberculosis: the hidden epidemic. Int J Tuberc Lung Dis 2004;8: 627-9.

5. Murray RA, Mansoor N, Harbacheuski R, Soler J, Davids V, Soares A, dkk. Bacillus Calmette Guerin vaccination of human newborns induces a specific, functional CD8 ${ }^{+}$ T cell response. J Immunol 2006;177:5647-51.

6. Brennan M. The tuberculosis vaccine challenge. Tuberculosis 2005;8:7-12.

7. Gray JW. Chilhood tuberculosis and its early diagnosis. Clin. Biochem 2004;37:450-5.

8. Britton WJ, Palendira U. Improving vaccines against tuberculosis. Immunol Cell Biol 2003;81:34-45

9. Sterne JA, Rodrigues LC, Guedes IN. Does the efficacy of BCG decline with time since vaccination? Int J Tuberc Lung Dis 1998;2:200-7.

10. Black GF, Weir RE, Floyd S, Bliss L, Warndorff DK, Crampin AC, dkk. BCG-induced increase in interferongamma response to mycobacterial antigens and efficacy of BCG vaccination in Malawi and the UK: Two randomised controlled studies. Lancet 2002;359:1393-401.

11. Eisenhut M, Paranjothy P, Abubakar I, Bracebridge S,Lilley M, Mulla R, dkk. BCG vaccination reduces risk of infection with mycobacterium tuberculosis as detected by gamma interferon release assay. Vaccine 2009;27:6116-20.

12. Brosch R, GordonSV, Marmiesse M, Brodin P, Buchrieser C, Eiglmeier K, dkk. A new evolutionary scenario for the Mycobacterium tuberculosis complex. PNAS 2002;99:3684-9.

13. Starke, JR., Smith M. Tuberculosis. In: Feigen R, Cherry JD, penyunting. Textbook of Pediatric Infectious Diseases. Edisi ke-5. Philadelphia: Saunders; 2004.h.1337-79.

14. Briassoulis G, Karabatsou I, Gogoglou V, Tsorva A. BCG vaccination at three different age groups: response and effectiveness. J Immune Based Ther Vaccines 2005;3:1-12.

15. Anuradha B, Santosh CM, Priya VH, Latha GS, Murthy KJR, Lakshmi VV. Age-related waning of in vitro Interferon- $\gamma$ levels against $\mathrm{r} 32 \mathrm{kDaBCG}$ in BCG vaccinated children. J Immune Based Ther Vaccines 2007;5:1-7.

16. Kalpana S, Prabha C, Kumarasamy V, Datta M. Invitro cytokine response in BCG vaccinated and non-vaccinated children. J Microbiol Biotech Res 2012;2:828-31.

17. Djuardi Y, Sartono E, Wibowo H, Supali T, Yazdanbakhsh 
M. A longitudinal study of BCG vaccination in early childhood: The development of innate and adaptive immune responses. PLoS One 2010;5:e14066.

18. Hendarto A, Sjarif DR. Antropometri anak dan remaja. Dalam: Sjarif DR, Lestari ED, Mexitalia M, Nasar SS, penyunting. Buku ajar nutrisi dan penyakit metabolik. Edisi pertama. Jakarta: Badan penerbit IDAI; 2011.h. 23-35.
19. Zaldivar F, McMurray RG, Nemet D, Galassetti P, Mills PJ and Cooper DM. Body fat and circulating leukocytes in children. Int J Obes 2006;30:906-11.

20. Rahajoe NN. Tuberkulosis. Dalam: Ranuh I, Suyitno H, Hadinegoro SR, Kartasasmita CB, Ismoedijanto, Soedjatmiko, penyunting. Pedoman imunisasi di Indonesia. Edisi ke-3. Jakarta: Badan penerbit IDAI; 2008.h.131-4. 